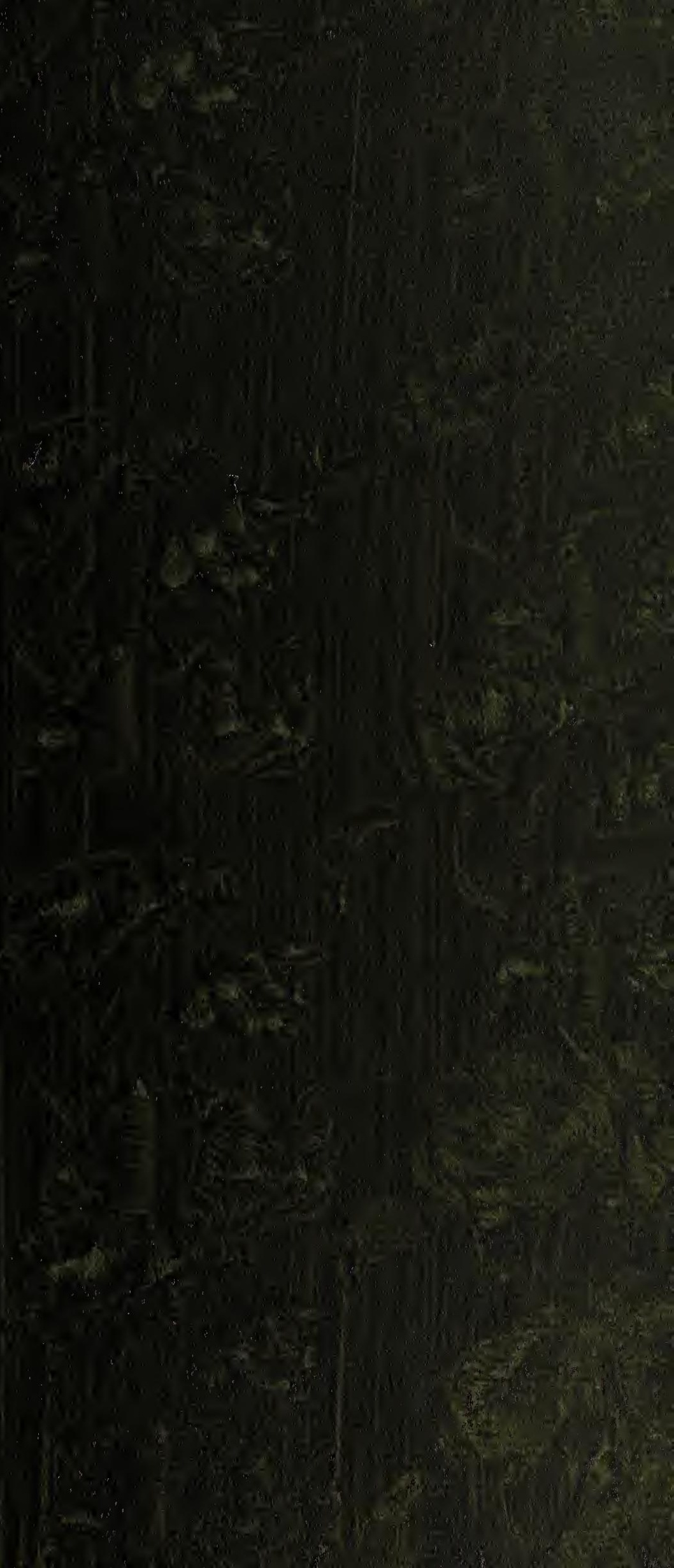


C.S.RAFINESQUE

Zoological rbotanical papers -

Also"the Fleasureo and duties of rue alct - 








\section{PLEASURES AND DU'TIES}

OF

\section{W EA LTH.}

\section{BY C. S. RAFINESQUE.}

\section{A. M.-PH. D.}

Professor of historical and natural Sciences, member of many learned Societies in. France, Germany, Belgium, Denmark, Switzerland, Italy and the United

States, ofc. Author of many works, \&oc.

In deeds of good import your wealth employ, And happiness bestow, yourselves enjoy.

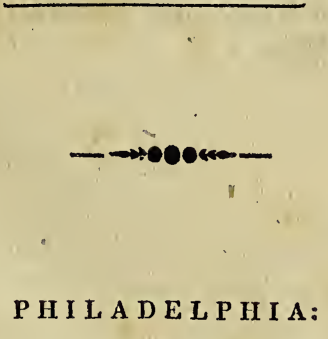

QRINTED FOR THE ELEUTHERIUM OF KNOWLEDGE.

1840 。 
The great poet LAMartine, has said in his travels in the holy land-The spirit of family is the second soul of humanity, Legislators forget this by thinking only of Nations and Inviduals; all ought to have a home and a field. . . . The social, political and religious worlds are not well organized, but are full of abuses .... the age of reason is coming, new ideas, new social forms are required. ....A religious, moral, social and political body, having a standard (of correct principles), a rule, a chief, an object, a true spirit, recalling Religion to mutual Love, politics to fraternal Love, property to charity and utility, their only titles and bases. . . Such would achieve the great reform of mankind, called for by millions ... the Cross and the Press are the two Engines that will achieve it-Let me add Wealth united to Love of God and Men. 


\section{THE PLEASURES AND DUTIES OF WEALTH.}

- 1, Ever since Cupidity became a human passion, the desire of acquiring Wealth has more or less prevailed among all Nations and Individuals ; often becoming their banes when the proper uses of Wealth have been forgotten.

2, Ever since Property was introduced as a reward of Industry, the wish to obtain, increase and secure its accumulation by Individuals, fâmiliés, corporations, tribes or Nations, has become paramount to all others; and this passion has often been gratified by very improper means, Injustice, Oppression, Strife and even Bloodshed .. . thro' Cunning, Force, War or Bad Laws: whether this desirable property was Land, Chattels, Estates, Money or Services.

3 , In the greedy pursuit after Wealth and Propirty, the human sinful Vices of Cupidity and Avarice, have been unfolded and gratified; nay indulged and encouraged by Social Laws, in spite of the precepts of Morality, Honesty and Keligion. Instead of Wealth being the reward of Industry, Sobriety and Prudence, it is oftener the consequence of Extortion, Monopolies, Speculation, Inheritance or even Despoiling ... disguised under the terms of fair trade, good luck, legal rights, \&c.

4, This had been perceived by the best Legislators, Nioralists and Founders of Religions : they endeavored to restrain the abuses and evils introduced by Cupidity, and the allied passions of Ambition, Avarice, Lust, Coveting, foc. . . but often in vain, the sinful propensities of mankind nearly overcoming all the nominal re- 
straints, unless coerced by direct laws, or guided by the holy Spirit of Charity.

5, If the holy Religion of Love To God AND Men, which we profess nominally, (but seldom effectually) has not been able to overcome thoroughly the evils of Cupidity, how are we to hope for the ultimate reform of mankind, un' less we endeavor to achieve whatever was inculcated by it. . . The love of our fellow beings, and the universal DIFFusIoN of happiness.

6, Perhaps, it was designed by Providence, that this prevailing passion, should be one of the means to be employed to attain the desirable end of mutual Concord and Happiriess. It is believed by many that several baneful Passions, if well directed or gratified to a certain extent, may evolve good results. Thus if Cupidity may be modified by Generosity, Patriotism, Benevolence, Learning or even Ostentation, Vanity, the Love of Glory, \&c. we might hope to see it exerted for the good of mankind, instead of the Vicious ends of Selfishness, Avarice, Pride or Cruelty.

7, But the great aim of this life being Happiness, and Enjoyments now and hereafter, if the possessors of Wealth can be persuaded to derive them from the pure sources of gratification that they can command, instead of the indulgence of vicious pursuits, it is certain that if they become convinced of this, they will neither refuse nor delay to seek and secure such pure enjoyments, that are besides in accordance with the human and divine lavs, and so likely to obtain our grateful approbation.

8 , Therefore it may be useless to ascend to the Origin of their Wealth, or try to impair its tenure, if improperly obtained; let us take the 
things as they are (altho' not always as they ought to be;) and try at least to improve them. Having ascertained that Wealth improperly used or wasted in Strife, War, Vices, Luxury, Gambling; \&c. becomes baneful to bodies and Souls, Men and Nations, let us show instead how useful it becomes when properly invested or 'employed in deeds of Peace, Charity, Science, Philanthropy, Education, Improvements and other attainments deserving and obtaining praise and reward now and hereafter.

9, Mankind has often been divided in two Classes, the Rich or Wealthy, and the Poor or Indigent; which have been ostensibly arrayed against each other ; but there is a third and medial class, which balances these two, and often happily preponderates : it is that nameless middle Class of Individuals neither rich nor poor, with a competence of property or emoluments or labor, that possess neither the superfluity of Wealth, nor dread the evils of poverty. To this Class we see'at all times ascending the industrious Poor or descending the prodigal Rich. It is this Class that forms the Nucleus and main strength of society, and to which if all could belong, there would no longer be to fear the evils of exuberant Wealth or destitute Indigence.

10, But even among Rich and Poor, a distinction must be made (not seldom forgotten) of the Worthy Rich or Poor, and the Vicious or Unworthy. The Vicious.Poor sink into Paupers, Mendicants, Droves, Thieves, \&c. while the Vicious Rich become Prodigals, Misers, Monopolizers, Tyrants, \&c.-Those exalted into Nobles, Lords, Kings. \&c. by peculiar Institutions, may be either Good or Bad, Worthy 
or Unworthy, Virtuous or Vicious, and thus produce extensive happiness or misery.

11, It is found that all Laws human and divine, are ineffectual to restrain those who unite great Wealth and power; they break them all whenever led by passion or whims. The very same effect takes place with the very Poor, who impelled by necessity, destitution and Hunger, must sometimes obey the great natural lavs, bidding human beings to preserve life and existence at any rate. Whence arise the great dangers of inordinate wealth or deep poverty in Society, which it is the duty of legislators and moralists to lessen by all practicable means.

12, Wealth is power, Knowledge is power, Industry is power! they all might combine to achieve the great aim of general security, morality and happiness. Wealth should furnish the means, Knowledge unfold the ways, Industry effect them. Yet if any one of them despises the others or does not value them, they become ineffectual and powerless for good purposes: while their triple power if continued, would be overwhelming. Union is strength, but Union of Powers is the Great Lever of Archimedes, the Lever that would move the moral, political and social Worlds.

13, The unshackled Industry of Men and Women, if not restrained by bad laws, and the competition of rivals, might of itself achieve much, since any labor can produce exuberant Wealth, particularly if aided by knowledge; but unfortunately Labor is apt to undervalue knowledge or improvements, and to lean towards the support of Wealth or Capital that feeds the Laborers at a higher rate of profits.

14, Competition is the great obstacle to un- 
obstructed production of food, and every other commodity. Both Industry and Knowledge feel its effect, there is a constant rivality among Laborers, producers, teachers, authors, \&c. because their exuberant labors may clog the markets. But Wealth hardly feels the effects of Competition, whence its superiority. Yet when moved by Cupidity, it tries to monopolize some objects, such as Land, or Corn, or Money. . . So as to make all other classes subservient.

15, There is a constant Strife between Wealth and Labor, to give more or less of each in exchange, whence the perpetual fluctuation of prices, their sudden rises and falls. If a correct and general standard of values could be found less variable than corn, labor or metals, a more adequate rate of equitable exchange could be introduced. Those who have proposed Labor have overlooked the quality of it, and the kind of knowledge required for its production.

16, Some have proposed Land as a measure of value, but it is so variable in quality, situation, improvements on it, \&c. that it will not do, and metals are yet the most useful and general, as they can command all others : therefore Labor, Industry, Knowledge and Wealth are measured by them, whether they be Gold or Silver, Copper or Iron, or else their equivalents.

17, Several means however exist to unite, bind and conciliate the three great Interests and Powers of Wealth, Knowledge and Industry, whereby to lessen the evil effects of Competition, and events enhance the effects of their combination, by multiplying the production of useful objects beyond conception, and thus the means of general enjoyments, while Wealth itself will be 
increased and adequately remunerated by a proportionate increase of enjoyments and delights.

18, Some modes altho' opposed to each other, may effect nearly the same purpose-They are 1. to establish a uniform High rate of values for every Property or Labor performed, neither being refused when tendered at that rate, but payable only in other Properties, effects, commodities or labors, equally high rated-2d. Or to adopt a Minimum or very low rate of valuations for every thing tendered payable or exchangable at the similar low rates-3rd. $\mathrm{Or}$ for any one to fix his own price to every thing, but be paid also in objects at the rate of the producer, this should be the voluntary plan.

19, Such practice or experiment of Highest and Lowest Values can of course be only used by mutual consent of a set of families, or Company, Association, or Community, large or small .... and their full effects and consequences can only be ascertained by practice on a large scale. But it is obvious at a glance that they offer such inducements and advantages to all, that provided the rates be justly equalized, whether High or Low, they cannot fail by their very disparity to suit most classes of Wealthy men, Laborers and Producers.

20, This may be called the Mutual System, those who may employ it will become MutualISTS, and either rates may be used separately or together. To unfold the practical benefits of both would require a volume: it may however be asserted that the High rates of exchanges will suit every body Rich or Poor, as every one will like to see its Land or Houses or Goods or Labor, rated at five-fold or ten-fold of usual prices, and obtain whatever he wants, altho' it may be 
at similar high rates. 'This will therefore invite Sellers or Exchangers, but may repel buyers.

21, On the contrary the Minimum of Low rates would invite buyers, but repel Sellers, unless divested of all Cupidity, and acting at last upon the beneficial plan of reducing all prices to the least metallic term of value, the best plan perhaps after all; but the Maximum would be most acceptable at first, wntil Cupidity is fully gratified and overcome.

22, Let us merely shew: the main effects of these two Mutual Systems. Maximum at ten-fold rates, the Wealthy Capitalist would receive 50 or 60 per Cent. interest: or profit on any Metalic Capital put in Mutual concern or exchange; while the Industrious Farmer would receive $\$ 2$ a pound for his butter, or $\$ 50$ for his flour, or the Laborer One Dollar per hour of labor .... . but never payable in ímetalic coin, but in Certificates of Exchanged Values.

23, At the Minimum rates, altho' the Capitalist might receive only one per Cent. per annum on his coin, he could obtain butter at two Cents the pound, flour at 50 Cents the barrel, labor at ten Cents per day .... and so on. If Capital is seldom tendered at this rate, yet when tendered at the high rates of 50 per Cent: it may be available for the few purposes where Coin may be indispensable, and by a nice calculation of High and low rates in ratio to fluctuating values will afford a fair profit even then.

24, It need not be said that there is a fallacy in these prices since they after all equalize each other: it is so, but their utility is this-very equity and equality, always unvariable! while all prices fuctuate around, and by availing of these fluc 
tuations, either the Individuals or the Managers of the Exchanges may be enabled to realize immense profits, buying at low prices, selling at high prices, and investing in unvariable rates, in which they ean always command the needful for comfort or use. By the Voluntary plan any objection to these are obviated, but Cupidity may avail itself of it to the detriment of good men, by overvaluing their own labors, \&c.

25, It will be easily perceived what advantage an Association, or Community or even Nation, would have over all others, by removing all checks to Industry and Production of all kinds, and storing for use whatever is produced; while Properties and Metallic Wealth would find an overwhelming inducement in the nominal increase of value, or if preferred in the very cheap attainment of all enjoyments and useful commodities.

26, If these Schemes however were to be applied merely as Speculations, they should offer. but a new. way of indulging Cupidity; the purpose for which contemplated, is far removed from. any such design. It is meant on contrary to check and control Cupidity by equalizing prices or rates, and Competition by opening a mart or marts for whatever Industry may produce to any extent, without ever any glut; affording adequate rewards to labor whenever depreciated.

27, In the great actual conflict of human passions and miseries, there are some Philosophers. who aim to better mankind, and lessen these miseries if not the passions, or avail themselves of these very passions to evolve some good. Altho their Schemes and Systems are widely different yet they all have the same aim, and if either can attain the object, they are surely wortily of en 
quiry and trial. Three of them deservo most notice as having already many believers or promoters. They are the Apostolic plan, 2d, the Mutual Plan, and 3rd the Social Plan.

28, The Apostolic or Evangelical plan of improving Mankind, is perhaps the very best, since it is the very Religion wo profess to believe. Deemed of Divine Origin, venerable by Age and good deeds, pure and holy when first promulgated and undefiled by human passions, it however admits and tolerates in our times of all the sinful practices of Paganism; of Wars, Quarrels, Lawsuits, Pride, Cupidity, Vices, Crimes, \&c. but fortunately it admits also and predicts a different Era to come, called a $\mathbf{2 d}$ Golden Age, or Millenium, when all these evils shall cease, and Justice prevail with Love and Charity, producing Happiness.

29, The majority of the nominal Xristians do not follow this Evangelical Religion, but are immersed in Sinful practices. There are however some Churches, Societies or Individuals, who aware of the Sins of the worldly throng, abstain from these evils, and dwell in peace, in or out of the Social crowd. Such are the Friends or Quakers, the Believers or'Shakers, the Moravians, Harmonites, Zoarites, Russian Quakers, and many others, who commonly live in communities as did the Apostles and follow the tenets of primitive Evangelical Religion.

30, To all Wealthy men who are righteous and pious, these Societies offer the means of doing much good, either by joining them, or by bestowing them Endowments for good and charitable purposes ; but each Society having been formed by ignorant (altho' well meaning) men or women, partake of their imperfection, and 
thus ignorance, cupidity or celibacy, or some peculiar tenets involve them in obloquy and restrain the friends of religion, by their absurdity or partiality.

31, But how easy and practicable for any Enlightened Worthy Man endowed with great Wealth, to become one of the Benefactors of Mankind, and Promoter of true Religion, by establishing himself some similar Society or Community of pious, industrious men and women, not to live as Monks and Nuns ; but to increase and multiply as fast as possible and fill the world with Evangelical beings.

32, Nay, this might be the way to hasten the Millenium so much desired and hoped for by the pious. Altho' so often foretold in vain; some hope it may happen in 1847 or a few years ! What glory for He who shall prepare it, or conciliate all the Sects by restoring them to the Single pure tenet of Love To God and MEn, from which shall flow all the other requisite blessings. This shall be the real Religion of the Evangelists, instead of our corrupt Sinful Sects.

33, Altho' all good deeds and endowments may contribute to lessen the human Miseries, yet a Single Man or a few Men, who would buy or give several large tracts of Land, and dedicate them forever to the perpetual use of good, temperate, peaceful, industrious families, that would live thereon in Evangelical Concord of mutual labor, help and instruction ... would thereby achieve a great victory over the Sinful World, and lay the foundations of the Evangelic and Apostolic tives to come, whether a millenium or something else.

34, There, this new Apostle, could become a Legislator and Reformer, he might suggest or 
establish perpetual Laws, neither restraining Marriage nor Industry, and proscribing only Quarrels, Intemperance and all Vices; neither dictating Tenets nor. Dogmas, but asking Mutual Love and Concord, from which naturally flow Happiness, Prosperity and Enjoyments of all kinds-Inviting all the good, the poor, the wretched, the unhappy of this World (of which millions exist) to come and dwell in peace in this Evangelic Asylum ; their labor and industry would amply support them, since they only ask and require a peaceful gratuitous asylum, instead of the heavy evils, rents, profits, taxes, \&c. to be paid in the corrupt Social State.

35. If only 100 families were collected, they would increase ten-fold in a few years; out of their Savings they could buy or procure other Lands, establish Colonies, multiply beyond belief, and form innumerable Clusters of happý Beings, ready for any further improvement. The System of families ought not to be broken, since fathers and mothers are the natural heads and patriarchs of their offspring: the patriarchal government could be restored by giving pre. ponderance to fathers and mothers of families, according to the size of their families. Industry and Knowledge ought also to be promoted by rewarding each according to their manual and mental labors.

36, As if to shame us, the Social plan of Owen and others, has lately been promulgated; altho' revived from the dreams of Plato, or the Cretan Laws, or the Pythagorean Schools, or the Hindu and Peruvian Communities; nay published $\mathbf{1 0 0}$ years ago in France. The Socialists or Owenists now claiming to be reformers also, (altho' discarding Religion and Moral principles 
or even the merits of Skill and Industry, have sipread in England and America, by turns successtul or desponding, they still cling to their infatuation, by adopting the principles of Social Harmony; which are in fact the practical part of the first Apostolic Communities, and the Essenians their progenitors.

37, Community of property has always been deemed a more perfect mode of life, and when the Nazarens or Evangelists became gradually Sinful Tristians admitting, Cupidity and other Vices, they yet venerated the 'Therapeuts or Monks and Nuns, that kept the practical tenet of conmon goods and labor. In order to restore the purity and further improve this very old Apostolic Dogma, it is only needful to add thereto the important improvement of adequate and proportionate reward of Wealth, Knowledge, Talents and Labor! acting in concord. 'Thus the banelul Social (or Anti-Social) tenets of Owen and others, will be banished, by the pure light and practice of Evangelical Concord.

38, This may be done by the Mutual plan, proposed in France by St. Simon, Fourier, Considerant and others; which they have unfortunately promulgated chiefly in theory, and drowned in long intricate details, whereby it is often difficult to ascertain their meaning. Fourier was so Sanguine as to suppose that the whole world would adopi at once his Scheme of Social or Mutual Phalanx; but he died before a single one could be fairly tried. He has left however zealous disciples, some of whom have reached America, and a Phalanx is said to be under trial near Paris:, while the St. Simonians attempting a New Sect, abolishing family ties, have been persecuted and dispersed. 
39, The pith of this new theory (if new it is) appears to be that all the luman passions are to be made subservient to useful purposes by their gratification; a dangerous principle if some baneful passions are not excepted. and evil propensities not controled when they inflict pain on others-However the utmost toleranee is inculcated which is right, and each Mruturalist or member of a Phalanx, is to be lodged, fed and treated in proportion to his capital, skill, talents, industry and activity.

40 , Such an ultimate plan is of course excellent and quite practicable, since it appeals at once to the interested passions of all, even $\mathrm{Cu}$ pidity, anity, Ambition, \&c. It admits also of as many separate and intricate bodies as our individual Society Systems, since as many Clubs or Associations for any purpose whatever can be formed within the Phaianx or Mutual Social Body, by any ose who choses or can.

4 i, Fourier contemplated a Hierarchy and Political System in his plan, that may not suit us ; but may do in Europe. He said that Nobles, Princes and even Kings might be members of his Social System, and become wealthier and more powerful thereby. We may have instead Legislators and Judges, Priests and Teachers, Generals (of peace) ant Presidents, and this may satisfy the ambitions.

42 , But to be' the Founder of a Mutual Cluster of Happy beings (which may be called an Eaben, Elysium, Agathon, Arcadia, Olbion or Eufopia) will gratify the highest ambition: and to do so, it is only required for a Wealthy man to set the example, and say, I wish to be happy by making the happiness of 1000 fellow beings, without losing a Dollar by it, since I ma 
give them my Estate or money in perpetuity, for which they will pay me a good annuity, or a perpetual income if I have heirs to gratify!

43, The inducements for Laborers under this Scheme is their mutual comfort and support, cheaper food and expenses by clubbing for cooking and every thing else, besides a proposal quite peculiar to make Labor as easy and pleasant as a festival. Ploughing, reaping, manual labor, \&c. are to be performed with songs, music and dances, just as if going to a wedding-This is certainly something new, (unless martial music for soldiers is a pattern) and altho' it may not suit the good followers of Penn, it will suit nine-tenths of Laborers and working men: four hours of daily labor or feasting will support any one and leave him twelve hours for study, reading, recreation, extra labor, exercise, meals, \&c. besides 8 for sleep. Competition is also to be abolished and the hardest work the best paid.

44, Altho' the mulualities were contemplated to be chiefly rural Communities, in order to raise the needful food; they might also be attempted in Cities, which are Centralities of Knowledge and Capital. A few houses put in common stock, some tools, shops, trades, \&c. might be sufficient to begin with ; but rents and profits that absorb nearly all the fruits of Labor. must be avoided as much as wages and extra expenses. By all being put in Common Stock for a term or forever, food, clothing, and Dividends might be procured at any rate for all concerned.

45. Such mutual plan if duly combined with religious Tolerance and Love to all men, might he still more successful any where. 'There will be no doubt many pious men who may give it a 
trial ere long, and if they do not split upon the rock of intolerance, or imposing their tenets on all their associates, it must eventually succeed on a large scale, but only partially if peculiar dogmas are to be dictated and assented to, or a monkish life inculcated.

46, If we suppose that there are no Wealthy men devoid of Cupidity, or liberal enough to dedicate a small share of their Wealth to improve Mankind at large, yet we know that there are many who either in life or death may bestow something for several useful purposes. We have seen some who thro' Ostentation have by their wills left cndowments for Hospitals, Colleges, Libraries, \&c. all useful purposes also; but very few indeed do it while alive and able to enjoy the gratification of seeing the good they devise.

17, Wills have been concealed, perverted or set aside, what is done while living is done according to the real intent, and can be enjoyed by the Donor as well as the public. Sir Isaac Newton has said . . they 'who gave away nothing till they died never gave at all... Ho meant because they could keep it no longer. Yet it is better to leave even by a proper will a share of superfluous wealth, than to leave all to Heirs who do not want the whole: while Millions of men destitute or suffering are craving for a small share of this bounty.

48, No religion inculcates more the need of charitable deeds, than our holy Religion, since the divine founder of it has explicitly said that, He who feeds the Hungry and thirsty, or who relieves miseries, verily does the same to Me! ... and ample rewards in Heaven are provided for those who perform this duty. Nevertheless how many neglect it, or only give to Churches 
and religious Societies, not mentioned in the Gospels.

49, The Gospel asserts that it is as hard for a Rich man to go to Heaven, as for a Cable (called Camel in Greek) to pass thro' the eye of a Needle ... the needle must be very large indeed that will allow it, and the Wealthy men who reach Heaven by good deeds performed while alive, (since they do not reckon after. death) are too few ... Hear it you Misers and Greedy holders of Wealth, and tremble! unless you be what you are ashamed to own, worshipers of Mammon by Cupidity and Hypocrisy, instead of the God of Heaven and Love.

- 50, In this we are put to shame by the pious Musselmen, who are enjoined to give one-tenth of their income or profits yearly in Alms or good deeds, and to leave as much when they die. . . They even may give the whole, and thus throughout the East have been founded pious Hospitals, Churches, Colleges, Bridges, Roads, Fountains, Inns. Schools, Libraries and other useful Works, all deemed Alms to the poor or the needy. Even the Jains of India and other Heathens d'eem such Alms a duty!

51, In Catholic Countries, altho' the priests often exact the Jewish tithe and admit of indulgences and other benefits to themselves alone, yet they inculcate the need of pious Works, -and Charitable Institutions are numerous every where, extending to all kinds of requisites for the poor even to provide them with work, tools, smail loans of money, \&c. or to teach trades and arts gratis, to educate orphans, give dowries to poor girls.... The only evil result is that by providing alms and food for the poor, they encour rage beggars and paupers. 
52, Meantime, how many pleasures are in reserve for the Wealthy, who discarding those arising from vicious indulgence or even mere luxury, find a delight in doing good, relieving distress, fostering merit and rewarding the worthy. .. Thrice happy are they, who beloved of God who has gifted them with wealth for good purposes, do not abuse their trust, but deserve the Veneration of their fellow men, by becoming their Benefactors, thro' the exertion of Benevolence, Charity, Generosity and Philanthropy. To such as these belong the joys of Earth and Heavens : they may be deemed Angels sent to comfort, relieve and lessen Human Miseries, or lead along the Sinful Mortals upon the paths of Celestial life.

53. The most obvious use (and duty) of Wealth is to procure happiness to us and others (Principles of Wealth 230)-Yes, happiness may be derived from this use, and whoever having the means that it supplies perverts them to bad purposes, or deny their use to those who may lack them, altho' as worthy as themselves. .. Such indeed are doomed to a sad fate, which they can hardly avert by death-bed restitutions to pious or useful purposes.

51, Hear what a poet has said....

Industry ought to earn, and wealth enjoy ...

Happy the men who seldom evils know

Never oppress the poor, but wealth bestow ....

When wisdom ruling us shall justice teach, The golden age again shall make us rich, The wealthy sharing well their ample store Shall jointly seek, the blessings we implore.

55, To suggest some of the public and private wants that may be supplied by Wealth properly applied, may perhaps induce some one to attend 
thereto, or at least sow the seeds of such improvements : since it is not always individual Wealth that achieves the most, but the contributions of many that can spare a little, have often effected as much. The widow mites and the penny subscriptions have sometimes realized beyond belief. The small sums spent by millions, in vicious habits of drinking, smoking, chewing, snuffing; law-suits and quarrels, \&c. could alone afford enough to change the face of the Earth if applied thereto.

56 , Of all such wasted savings, the greedy priestly or political leaders try to divest their tools, and often succeed altho' their purposes are not always pure. Ever since the Churches have drunk of the baneful Cup of Cupidity, they are become corrupt and unworthy of cordial support. It will be better to apply the Super:fluity of Wealth and the petty Savings of Industry (which amount to a great deal when extensive or often renewed) to the purpose of actually benefiting the very Donors or Contributors.

57, Patriots recommend the patronage of Education, Colleges, Libraries, Schools, Agriculture, Arts and Sciences, Learning, Useful Books and other objects, connected with the general increase of knowledge, and improvement of mankind. All these objects are commendable, and too much can never be done to foster the nurseries of knowledge, supply the wants of youth and even older age by study or: otherwise. Popular Lectures have been effectual in inculcating or teaching what many men will not seek in looks, and therefore are equally useful. To endow firee Lectures, Museums, Libraries and other Sources of $\mathrm{K}$ nowledge, are among the most noble and praiseworthy pleae 
sures and duties of wealth, but most of ours are as yet venal.

58, Those who befriend Genius when it is struggling for distinction, befriend the World, and their names should be held in remem. brance (Cunningham's Life 'of W West)-Yes to seek, foster and protect. Genius is one of the highest prerogatives of Wealth. Génius however is not confined to Painters or Machinists, it applics and belongs to all Inventors, whoever seeks, finds and makes known useful or valuable facts or things, to Original Authors, Poets, Dramatists, Philosophers, Historians, Naturalists, Botanists, Astronomers, ... as well as Manual Laborers, from the inventor of Sandals or Shoes, to that of Steam Engines and Telescopes. To all these the friendly help or patronage of Wealth is needful at present; in a better state of Society, it would be the duty of the public to reward them.

59, Dr. David Brewster has said-The labors of Science have no counterpart of evil, they are the liberal bequest of great minds to every individual of their race. Wherever they are welcome and honored they become the solace of private life, the ornament and bulwark of the Commonwealth.-Such eulogy is deserved; but as such men are seldom gifted also with Wealth like Humboldt or Banks, it is the duty of Wealth to patronize such exalted merit. In Europe the Savans or Learned begin to form a High Class, not so with us as yet; but it may be so ere long, a real Nobility accessible to all talents.

60 . If it is asked how patronage is to be exerted, it may be answered-Honor the Men of Genius and Learning, publish or buy their works, their talents, the labors of their hands and $3^{*}$ 
minds, give them rewards or medals, make them happy in life and old age, do not allow them to fall in neglect to poverty . . There are many ways to evince our respect and sylapathy for these benefactors of mankind, they will suggest themselves when opportunities offer. Wealth by fostering Talents, Science and Genius partakes of their immortality.

61, A general belief prevails that Benevolence or Charity ought to exert itself chiefly on the Sick, the Blind, the Deaf and Dumb, the Cripples, the Orphans, the unfortunate of all classes ... and these are thereby well provided for in many instances, while we forget the Indigent by misfortune, lack of work, the oppressed, the persecuted, the distressed, the old and infirm, the Invalids, the men ruined by Accidents,'Shipwrecks, Fires, Casualties . ... with many more unfortunate beings, all equally deserving the help of Wealth to be restored to happiness or comforts.

62, Asylums for old age exist in some parts of Europe, and are quite as needed as Orphan Asylums. They are unknown as yet with us, where old age often meets with neglect. They. might be established by Wealth, or even by Associates paying small rates for years previous or a cheap board in some easy labor, or by teaching .... How grateful to see venerable Men or Women bless you, if you should provide such an Asylum; a small farm will do, some proper buildings might be added, a school kept by Veterans of all professions might be very useful. Such Asylums only exist among the Moravians, but we ought to have one in each County. It is not in poor houses that disabled 
or venerable age ought to be confined, nor mixt with the Vicious Poor that are its tenants.

63, We build extensive Palaces or Castles for Prisons, Houses of Refuge, Penitentiaries and Poor Houses, spending Millions thereon, and we do not yet build modest suitable houses for honest reduced families or Individuals, willing even to work; but shrinking for the contamination of Felons, Drunkards and Vicious poor-The Felons, Convicts and Delinquents are better treated than honest Indigence or decay-Shame upón us for it-Open your hearts and purses you Men of Wealth, and fulfil this duty by providing little farms or houses for the honest and sober poor or aged Men or Women, or destitute chiidren, and allowing them to work for you there if able.

64, Colonies afford the means to relieve much human misery. We have only attempted to colonize the fiee blacks in Africa : do not the free whites deserve as much care? We have within our States ample room and scope for many such Colonies of worthy families, unable to buy even our cheap Lands. Wealthy men if generous could buy large tracts of land and retail it in small farms at cost, or with simple interest added till paid, when convenient and able thro' their labor-But Cupidity bids our Wealthy men to buy at $\$ 1.25$ per acre and resell to the poor at $\$ 2,3$ or 5 .

65, Even Tenants on perpetual Leases of 8 or 10 Cents per Acre might gratify the desire of perpetual Wealth and command the gratitude of good Colonists, but it is not enough, and tenants are not yet to be found on the hard terms exacted-Learn wisdom men of wealth, lessen your demands, and offer cheap bargains to nee- 
dy good families, which will be bound to you by respect and gratitude for this and other benefits you may devise for them in happy Colonies.

66, But far more distant Colonies could also be attempted ; England is now colonizing Australia, New Zealand, South Africa, the Falklands, aiming next to Patagonia, California, Madagascar, Papua, \&c.-We have within our limits Florida and Origon . . . Texas has been begun altho' thro' violent means. 'The Earth is not yet half filled with human beings, while millions are still wanting lands or locations. To help them is a noble achievement, the founder of new Colonies may become equal to William Penn or Roger Williams if led by the happy genius of tolerance like' them.

67, To foster Commerce is a public duty and the trade of merchants, but men of Wealt/ may increase it while they patronize it ; they might send trading Ships as well as Whaling Ships all over the world, to seek and open new channels of trade, to collect the Botanical, Zoological and Mineral treasures of the shores and the deep ocean : many Lands and Islands little explored as yet are replete with novelties and treasures of Natural History for our Colleges, Museums, Ec. such are all the shores of East Africa, Borneo, the Moluccas, Papua or New Guinea; North Australia, and even those of Mexico, Guatimala, Guayaquil, Brazil, \&c.

68, Roads, Bridges, Canals, and even Churches, \&c. are built with us by Corporations or Individual contributions for gain; but we lack free Instilutions of all kind, where tuition or admission be gratuitous ; free Schools, Colleges, Museums, Libraries, and even Churches: inany are repulsed by compulsory taxation from the actual 
Institutions. .. Iabor Schools and Colleges, Mutual Libraries and Museums, would obviate to this defect. Intolerance has invaded our Lecture rooms and Persecution has struck the Mormons and Abolitionists, even if they be fanatics, it is a sad blot on our boasted freedom! May Providence avert the recurrence of such foul deeds and the penalty of the incured iniquity. I

69, Labor Schools, both for male and female children and adults, are the most useful of all ; few means are required to establish them, a small farm or a piece of Land, all the buildings may afterwards be raised by the labor of the Students! Some Donations of Books, or small endowments for needful expenses are useful, the teachers and students will afterwards be supported by the Land. They ought to be established by thousands, nay all other schools be changed into these ; the ample funds of all the States for School purposes would afford them all the requisites. In the Western States there is Land already beyond their need if applied thereto out of the School Lands.

70, To these may be united Botanical Gardens, Agricultural Schools, to improve Farming, tools, machinery and procure or spread useful plants, either domestic or exotic, useful for medical, tinctorial, and feeding purposes, raising Oil, Sugar, Wax, Honey, Silk, \&c. Such schools well endowed are scattered all over Europe, but yet unknown with us-Any Farmer that can spare 100 Acres of Land could establish one, after some years they support themselves.

71, These Schools would be the best Asylums for Orphans, male and female, instead of crowding them in Cities or Splendid buildings ; they rather require country air, labor, exercise 
and good food raised by themselves-Asylums of young females or Widows, so much required with us, instead of the Nunneries of Europe, would also be best in farms or small villages, where food is cheap, and their fabor at the needle or otherwise would amply support them: nay they might become excellent female schools.

r2, All such useful Institutions should be pui on the safe footing of security by good perpetua. deeds, so as to insure their perpetuity and constant useful purposes for ages to come, for the use of those wishing to avail themselves of their benefits at any time, without ever refusing any one, but forming branches when too crowded. Altho' we cannot foresee futurity nor prescribe laws for very late generations, yet we can effect. the good contemplated to last until our designs and Institutions may be merged into something better, brought on by the lapse of time. We shall have the gratification of seeing the good performed, the merit of overcoming the difficulties of the outset, and be able to say- We have not lived in vain on this Earth, since we have done some good, and tried to make it permanent.

73, If piously inclined, we may base our Institutions upon the religious command's, but without exacting superfluous tenets, since charity does not acknowledge them-If otherwise inclined, we may base them on the universal Benevolence of correct minds, or even upon the mere cold system of utility; but let us beware to intrude therein the delusion of fanatical Sects, whother religious or anti-religious. It will always be vain to act against the human nature of self inierest as some propose, and still worse if 
we will not grant any merit in good deeds, talents, activity, industry, \&c.

74, Let us rather admit self interest as the leading motives of our conduct, foundations, Institutions, \&c.-and grant the utmost latitude to merit; by praise and rewards for donations, abilities, inventions, for useful or agreeable performances. Piety and Charity derive their sanction from the hope of happiness here and hereafter in the Worlds of glory and bliss swarming in the Celestial Regions. Those who deny themselves the Hope of Heaven thro' disbelief or Vicious Cupidity, must be satisfied with making themselves less wretched in this life. But how superior to them, are the Happy minds that seek to reach the Heavens, thro' the paths of Charity and good deeds, thus becoming happy here and hereafter, and conferring the same hope and happiness to many fellow beings.

75, Tue Besetring National Sin of AmeRIca Is Cupidity - To make money any how, to obtain it fairly or unfairly, is the great aim of Life-While the repairing corrective may be to spend it properly and usetully when acquiredIf Money procures with us Influence, Regard, Reputation, Friends and even a Pseudo-Nobility, altho" spent in Ostentation, and Selfish gratifications; when spent to better purposes of public or general benefit, it would no doubt command Respect, Esteem, Approbation and Gratitude....

76, But if Worth, Merit, Probity, Sincerity, Talents, Industry, Zeal, Fortitude, Knowledge, Benevolence, and all the other Virtues or qualities adorning Mankind, were to be united to Wealth in the sime Individual, or fostered by Wealth when separated, so as to act jointly in 
improving Mankind and Society ... they would deserve and obtain universal Admiration, Veneration and Love.

77, There are some desponding minds that consider almost every attempt at moral improvements as either useless or ineffectual. Such have said that altho' Experience has been accumulating ever since Creation, it hardly avails, Reason bidding in vain to make past errors our Wisdom. But nevertheless Mankind has always been improving, (with occasional relapses) in a moral, social and physical sense. It is ignorance, apathy and neglect that delay and thwart all improvements in Science, Religion, Knowledge and Human weal; while the contrary tendency of Knowledge, Hope, Zeal and Talent can effect every thing desirable.

78, How long has the pulpit existed to teach us our duties, with laws, jails and gallows to enforce them! and yet they hardly avail; they punish but do not prevent, they never attack $C u$ pidity since they thrive on it, and many other Vices are equally overlooked or even fostered. ... It is vain to talk of right and justice to starving men; Hunger, want, misery, \&c. are more powerful than Conscience, and will ever be, as long as Wealth does not provide for their relief. Every family ought to be above the fear of ultimate penury: Charity bids to effect this, but Cupidity and Pride (the Satanic Vices) delay it or prevent it.

79, Is it not more important to help our neighbors and make them happy, than to spend millions in Missions to Heathens often happier than we are, to offer them the gift of our corrupt, sinful and warring Sects, training millions of Soldiers to kill and be killed by turns, in the 
name of the Religion of Peace; or else to poison them with Opium, Rum and Tobacco with one hand, and tender them the Mistranslated Bible with the other ... But when Charity and Love shall have conquered with us Cupidity and War, we might then endeavor to spread all over the Earth, the holy Religion of Peace and Love. The Societies of Peace and Temperance with others acting on the true holy principle are but beginning the work of Reform, Concord and Love, which Wealth may achieve thro' many other channels.

80, Let us conclude by the following quotation from the Celestial philosophy page 130-MeN of Weactu! who blest with the superfluities of accumulation, are yet surrounded with human wretchedness, learn to relieve it and to practice the difficult art of Dorva Goon to many, making your Charity diffusible like the Divine Light and Love-but discarding Cupidity and Avarice that lead you to perdition, in the worship of the Idols of Self and Pelf-

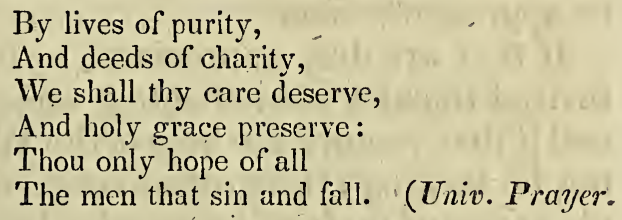

\section{RESULTS.}

1, Therefore it is evident that the main Duty of Wealth is to employ a share of its superfluity in good deeds. By doing so the Wealthy will secure the best human pleasures, those of beneficence, and moreover obtain the celestial rewards of good actions.

2 , This must be done while alive, in order to $4^{*}$ 
have the full merit, enjoy public approbation, and avoid the evils of delay or misapplication.

3, A single Wealthy Individual might hasten, (or be the precursor of) the expected Millenium of Ilappiness and Justice, by a proper use of his ample means to redeem human miseries.

4, In Selecting how to apply Wealth to good purposes, we ought to prefer those purposes which may be beneficial to the greatest number in perpetuity.

5, Endowments of Charitable and Benevolent Institutions, Asylums, Associations ... for gratuitous Education. Spreading $\mathbf{K}$ nowledge, relieving evils and miseries, or procuring general happiness . . a appear to be the mosi suitable of all.

\section{NOTICE.}

If the Wealthy to whom these Inducements to good deeds will be presented, are not liberal enough to value them, they are requested to hand them to some one more generous or calculated to appreciate them.

If they are duly appreciated by them, they are invited to shew it by effecting some good deeds, and if they require the help of the Writer, it shall not be lacking; his gratuitous services and ample stores of tools of linowledge being dedicated to effect the greatest available purposes of a useful perpetual tendency.

If any one of them wishes to be grateful towards the Eleutherium of Knowledge, established to promote free Education and Universal Benevolence, they may either purchase the Works already issued, or give a trifling mite to enable to continue these publications, and spread the seeds of good purposes. 


\section{ELEUTHERIUM OF KNOWLEDGL.}

Established in 183\%, to promote free Institı:tions and Schools, the free diffusion of knowledge, by publishing Works, Pamphlets, Journals, free Lectures, exertions, \&c.

No Contribution exacted, each Member or Associate must have the merit to tax himself, or give whatever he pleases or can afford in money, labor, materials, \&c. Every Dollar of Donations entitles a Member to a Vote.

This Institution aims also at establishing Labor Colleges and gratuitous Schools in several States; and to colonize honest temperate families, providing them with perpetual farms payable in Labor at the mere cost.

Every benevolent and charitable object aiming to improve mankind, and to promote ultimate happiness by means of Peace on Earth and good will to all men, shall be fostered as far as the means will allow.

\section{WORKS AND PAMPHLETS,}

\section{PUBLISHED BY THE}

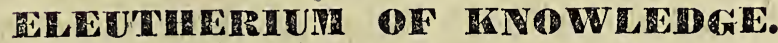

Theory of the Visible, Creation by 'Thomas Wright, Astronomer, 1750-re-printed with notes, 1837 _ $75 \mathrm{Cts}$.

Celestial Wonders and Philosophy of the Visible Heavens, with Theory of Futurity, 1838$50 \mathrm{Cts.}$ 
Genius and Spirit of the Orir or Hebrew Bible, 1838-\$1, 10 Copies for \$5.

Improvements of Universities and Colleges, 1839 - pamphlet given gratis.

Manual of the Mulberry Trees, 40 kinds $_{q}$ 1839-50 Cts. 25 Copies for $\$ 5$.

Whe Improver, Monthly Journal, 1840-12 Cents per annum-New Aurora, 1837, given gratis.

Some late Worles of Professor Rafinesque -American Nations before Columbus, 2 Vol. $\$ 3$ - Medical Flora of the United States, 2 Vol. 100 figures, $\$ 3$-Instability of the World $\$ 1.50$, five copies for \$5-Trees and Shrubs of North America, \&c. \$5-New Botany of North America, 4 Vol. \$5-Flora Telluriana, 4 Vol. \$5Life of Travels and Researches, 75 CentsFishes and Shells of the River Ohio, $\$ 5-$ Autikon Botanikon or Figures of New and Rare Plants, text 50 Cents per part of 500 , the figures $\$ 50$ for each 500 - Amenities of Nature, New Animals and Plants, Principles of Wealth, The Pulmist, Ancient Monuments of America, \&c.

Adpition to article $75-$ If we believe that Money is the root of all Evil (Gospel,) why are we so greedy to obtain it and keep it? or why not do without it? . Nothing easier as soon as some families will supply all needful wants to each other, having obtained a location from Wealth and Benevolence. 




$$
320
$$


